\title{
An Efficient Electron Transport Material of Tin Oxide for Planar
}

\section{Structure Perovskite Solar Cells}

Govindhasamy Murugadoss, ${ }^{* a, b}$ Hiroyuki Kanda, ${ }^{a}$ Soichiro Tanaka, ${ }^{a}$ Hitoshi

$$
\text { Nishino, }{ }^{\mathrm{c}} \text { and Seigo Ito }{ }^{\mathrm{a}}
$$

aDepartment of Electric Engineering and Computer Science, School of Engineering, University of Hyogo, 2167 Shosha, Himeji, Hypogo 671-2280, Japan

${ }^{b}$ Electrochemical Materials Science Division, CSIR-Central Electrochemical Research Institute, Karaikudi 630006, Tamilnadu, India

'Energy Technology Laboratories, Osaka Gas Co., Ltd., 6-19-9 Konohana-ku, Osaka 554-0051

$$
\text { Japan }
$$

\begin{abstract}
The photovoltaic performance of a perovskite solar cell based on a new electron conducting $\mathrm{SnO}_{2}$ film prepared at low temperature using different solvents was investigated. $\mathrm{SnO}_{2}$ was selected as an electron conducting medium due to its superior properties over $\mathrm{TiO}_{2}$, such as better antireflective properties, higher electron mobility, more suitable band edges and a wider band gap. A $\mathrm{SnO}_{2}$ layer was developed by spin-coating $\mathrm{SnCl}_{2}$ solution followed by annealing at $200^{\circ} \mathrm{C}$ in air. The low-temperature $\left(200^{\circ} \mathrm{C}\right)$ annealed $\mathrm{SnO}_{2}$ layer exhibits enhanced crystallization, high transmittance, and uniform surface morphology using ethanol as a solvent rather than water. Solid state $\mathrm{CuSCN}$ hole conductor was used as HTM for reducing the device cost. A planar solar cell fabricated with $\mathrm{CH}_{3} \mathrm{NH}_{3} \mathrm{PbI}_{3}$ perovskite infiltrated $\mathrm{SnO}_{2}$ showed a power conversion efficiency of $8.38 \%$ with short-circuit current density of $18.99 \mathrm{~mA} / \mathrm{cm}^{2}$, an open-circuit voltage of $0.96 \mathrm{mV}$ and a fill factor of $45 \%$. The devices were fabricated at $>60 \%$ humidity level at room temperature. The results suggest that $\mathrm{SnO}_{2}$ is an effective charge collection system for $\mathrm{CH}_{3} \mathrm{NH}_{3} \mathrm{PbI}_{3}$ based planar perovskite solar cells. In addition, these results
\end{abstract}


provide a new direction for the future improvement of perovskite solar cells using new electron conducting layers.

Keywords: $\mathrm{SnO}_{2}$; CuSCN; Perovskite; Planar structure; Two-step process

*Corresponding author Tel.: +919894424828.

E-mail address: murugadoss_g@yahoo.com (G. Murugadoss)

\section{Introduction}

Organometallic halide perovskites $\left(\mathrm{ABX}_{3}\right)$ have drawn much attention over the last several years and are currently under intense investigation [1-5]. The outstanding absorption properties, such as a high absorption coefficient and suitable band gap, make this material very appropriate for light harvesting applications in photovoltaics. The power conversion efficiency (PCE) of the first perovskite-based solar cell device reported in 2009 was $3.8 \%$ [6], but the certified efficiency has recently reached $20.1 \%$. Development and improvement of the perovskite devices have been attained using different approaches, such as modifying the nature of the halide, the metal, or the cation group of the materials, as well as the development and optimization of novel fabrication techniques [7-11]. However, selective electron transporting materials (ETMs) and hole transporting materials (HTMs) were used for the high efficiency device.

$\mathrm{TiO}_{2}$ exhibits electrical conductivity only after the formation of nanocrystallites. Therefore, the formation of $\mathrm{TiO}_{2}$ crystallites at a low temperature is necessary for the preparation of $\mathrm{TiO}_{2}$ ETMs. However, the preparation of low-temperature $\mathrm{TiO}_{2}$ ETMs is relatively complicated because crystallization of $\mathrm{TiO}_{2}$ is difficult. Although $\mathrm{ZnO}$ possesses high electron mobility and can be also used as an ETM for photovoltaic solar cells [12-14], it is chemically unstable and reacts easily with weak acids or bases. Efficient electron mobility of $\mathrm{ZnO}, \mathrm{TiO}_{2}$ and $\mathrm{SnO}_{2}$ nanostructures has been recently reported [15]. A high electron mobility was observed for $\mathrm{SnO}_{2}\left(0.8 \pm 0.14 \mathrm{~cm}^{2} / \mathrm{V} . \mathrm{s}\right), \mathrm{ZnO}\left(0.08 \pm 0.01 \mathrm{~cm}^{2} / \mathrm{V} . \mathrm{s}\right)$ and $\mathrm{TiO}_{2}(0.1 \pm 0.03$ $\left.\mathrm{cm}^{2} / \mathrm{V} . \mathrm{s}\right)$. Thus, the development of new technology or new functional materials is required for 
the preparation of ETMs at low temperature with simple processes. 2,2,7,7-Tetrakis-(N,N-di-pmethoxyphenylamine)-9,9-spirobifluorene (Spiro-OMeTAD) is typically used as an HTM in conventional-architecture perovskite cells. However, Spiro-OMeTAD is relatively expensive, which may limit the future development and application of this type of solar cells. Recently, doctor-bladed $\mathrm{CuSCN}$ has also been used in a conventional-architecture perovskite cell (i.e., CuSCN deposited on the perovskite) and a high efficiency was reported [16]. In the present work, doctor-bladed CuSCN film was selected as the HTM layer due to its excellent transparency in the visible light spectrum range, high hole mobility, relatively good chemical stability and simple preparation process [17-20].

Here we report a fabrication procedure and device performance on low temperature processed $\mathrm{SnO}_{2}$ ETM materials for perovskite solar cells using $\mathrm{CH}_{3} \mathrm{NH}_{3} \mathrm{PbI}_{3}$. $\mathrm{SnO}_{2}$ nanoparticles have good antireflective properties, wide band gap, less photocatalytic activity, high electron mobility and thermal stability. $\mathrm{SnO}_{2}$ has been used in polymer-based solar cells and dye-sensitized solar cells with good performance [21, 22]. More rcently, $\mathrm{SnO}_{2}$ used as ETM in perovskite solar cells prepared at high annealing temperature and organic hole conductor [2326]. However, there is no report on efficient perovskite solar cells using low-temperature processing $\mathrm{SnO}_{2} \mathrm{ETM}$ with high stable solid state hole conductor. In addition, this work focuses on the use of different solvents for the preparation of $\mathrm{SnO}_{2}$ layer for planar perovskite solar cells by solution processed method. Perovskite was deposited on $\mathrm{SnO}_{2}$ ETM layer by both one step and two step methods for comparison. It has been reported that morphological control is very important for solution-processing planar heterojunction perovskite solar cells [27]. For mesostructure perovskite solar cells, the morphology of the perovskite and crystal structure of the perovskite films also play important roles in determining the photovoltaic performance [28, 29]. To fabricate an efficient perovskite planar $\mathrm{SnO}_{2} / \mathrm{CH}_{3} \mathrm{NH}_{3} \mathrm{PbI}_{3} / \mathrm{CuSCN} / \mathrm{Au}$ solar cells, a new $\mathrm{SnO}_{2}$ electrode used as electron-blocking as well as electron-conducting layer using different 
solvents, while dimethyl formamide (DMF) and 2-propanal were used to prepare $\mathrm{PbI}_{2}$ and methylammonium iodide (MAI) solutions, respectively.

\section{Experimental}

\subsection{Preparation of MAI}

MAI powder was synthesized according to the method described by Wang et al., [30] $15.0 \mathrm{~mL}$ of concentrated aqueous hydroiodic acid (HI; $57 \mathrm{wt} \%$ in water, Alfa Aesar) was reacted with $13.5 \mathrm{~mL}$ of methylamine $\left(\mathrm{CH}_{3} \mathrm{NH}_{2} ; 40 \mathrm{wt} \%\right.$ in aqueous solution) in a beaker at $0{ }^{\circ} \mathrm{C}$ (ice bath) for $2 \mathrm{~h}$ with constant stirring under air atmosphere. MAI was crystallized by rotary evaporation of the solvent. The white powder product was collected after washing three times with diethyl ether and ethanol, and then drying under vacuum at $60{ }^{\circ} \mathrm{C}$ overnight. The dried MAI powder was stored in a dark room until use.

\subsection{Device Fabrication and Characterization}

The solar cell devices were prepared on clean FTO coated glass (FTO, TEC-15 ( $\mathrm{t}=2$ mm), NSG-Pilkington). A blocking layer of compact $\mathrm{SnO}_{2}$ was formed by spin-coating a precursor solution of $0.1 \mathrm{M}$ tin chloride in $5 \mathrm{~mL}$ of ethanol at $2000 \mathrm{rpm}$ for $30 \mathrm{~s}$. The film was then gradually heated to $200{ }^{\circ} \mathrm{C}$ and sintered at that temperature for $1 \mathrm{~h}$. The deposition of tin chloride was repeated to ensure full coverage of the FTO with $\mathrm{SnO}_{2}$. After cooling down the film at room temperature, $1 \mathrm{M}$ solution of lead iodide in DMF was spin-coated onto the $\mathrm{SnO}_{2}$ at $4000 \mathrm{rpm}$ for $30 \mathrm{~s}$, and dried at $70{ }^{\circ} \mathrm{C}$ for $30 \mathrm{~min}$. The perovskite layer was formed using a twostep method; after drop-casting $0.1 \mathrm{~mL}$ of $\mathrm{CH}_{3} \mathrm{NH}_{3} \mathrm{I}$ solution in isopropanol $\left(10 \mathrm{mg} \mathrm{mL}^{-1}\right)$ onto the substrate, and after waiting for $30 \mathrm{~s}$, spin-coating for $30 \mathrm{~s}$ at $4000 \mathrm{rpm}$. The substrates were then dried at $100{ }^{\circ} \mathrm{C}$ for $30 \mathrm{~min}$. The CuSCN HTM layer was then deposited by doctor blading at $80{ }^{\circ} \mathrm{C}$. The HTM solution was prepared by dissolving $6 \mathrm{mg}$ CuSCN (Kishida Chemical Co. Ltd.) in $1 \mathrm{~mL}$ of propyl sulfide. The device architecture was completed with a $50 \mathrm{~nm}$ gold counter electrode, which was thermally evaporated onto the top of the device. The active area of the device was $0.25 \mathrm{~cm}^{2}$. 


\subsection{Characterization}

The crystal structure was characterized using X-ray diffraction (XRD; Miniflex II, Rigaku) with $\mathrm{Cu} \mathrm{K} \alpha$ radiation. The surface morphology and cross sections of the samples were investigated using high-resolution scanning electron microscopy (SEM; JSM-7400F, Jeol, accelerating voltage: $15 \mathrm{kV}$ ). UV/vis absorption spectroscopy (Lambda 750, Perkin Elmer) was measured in the range from 400 to $800 \mathrm{~nm}$. Current density-voltage $(J-V)$ curves were measured for samples with a cell area of $0.25 \mathrm{~cm}^{2}$ by application of an external bias to the cell from the 0 to $1 \mathrm{~V}$ (forward bias scan) and measuring the generated photocurrent with a DC voltage current source (6240, ADCMT, Japan) under a solar simulator (AM1.5 irradiation, $100 \mathrm{~mW} \mathrm{~cm}{ }^{-2}$, calibrated with a standard photodetector (Bunkou Keiki, Japan)) equipped with a $500 \mathrm{~W}$ Xe lamp (YSS-100A, Yamashita Denso, Japan). To consider the photovoltaic effects of the solar cells, the results of reverse bias voltage scans were eliminated because these can lead to overestimation of the results [31]. Thus, all results presented here were obtained from the forward-bias voltage scans. The differential hole-transport resistance and recombination resistance $\left(R_{r e c}\right)$ were determined by electrical impedance spectroscopy (EIS) measurements in the dark at various bias voltages between 0.55 and $0.70 \mathrm{~V}$. The EIS spectra were measured using a potentiostat (SP-150, Bio-Logic) and Zview2 software was used for the fitting. The differential resistances given represent the average for three different cells.

\section{Results and discussion}

To make a systematic comparison of the effect of solvent on the performance of planar photovoltaic device with a compact $\mathrm{SnO}_{2}$ layer, thin film $\mathrm{SnO}_{2}$ was spin-coated onto patterned FTO on a glass substrate. A two-step spin-coating method was used to fabricate the $\mathrm{CH}_{3} \mathrm{NH}_{3} \mathrm{PbI}_{3}$ perovskite layer for the planar devices. Figure 1 shows evidence for the tetragonal structure perovskite with peaks at $2 \theta$ of $14.08^{\circ}\left(\begin{array}{lll}1 & 1 & 0\end{array}\right), 28.5^{\circ}\left(\begin{array}{lll}2 & 2 & 0\end{array}\right)$, and $31.7^{\circ}\left(\begin{array}{lll}3 & 1 & 0\end{array}\right)$ [32]. The peak at $2 \theta=12.8^{\circ}$ attributing to the $\mathrm{PbI}_{2}$ phase just displays a weak intensity [33], indicating that the $\mathrm{CH}_{3} \mathrm{NH}_{3} \mathrm{PbI}_{3}$ perovskites with high purity were successfully prepared on $\mathrm{SnO}_{2}$ film by 
two-step method. In the two-step method, the conversion of $\mathrm{PbI}_{2}$ to $\mathrm{CH}_{3} \mathrm{NH}_{3} \mathrm{PbI}_{3}$ was incomplete after depositing, with the $\left(\begin{array}{lll}0 & 0 & 1\end{array}\right)$ peak of $\mathrm{PbI}_{2}$ still remaining, as shown in Fig. 1. It was speculated that $\mathrm{CH}_{3} \mathrm{NH}_{3} \mathrm{I}$ in the solution could not penetrate into $\mathrm{PbI}_{2}$ thin film so that some $\mathrm{PbI}_{2}$ further away from the surface remained unreacted. The relative intensity of the $\mathrm{PbI}_{2}$ peak $\left(12.8^{\circ}\right)$ was notably reduced when ethanol was used as the solvent for $\mathrm{SnO}_{2}$ preparation. The more conversion of the perovskite indicated good smoothness of the under layer $\left(\mathrm{SnO}_{2}\right)$ film using ethanol as solvent than the water.

Figure 2a shows comparison of UV/vis absorption spectra for the $\mathrm{FTO} / \mathrm{SnO}_{2} /$ perovskite film where the $\mathrm{SnO}_{2}$ layer was prepared using water or ethanol as the solvent. The absorbance of $\mathrm{CH}_{3} \mathrm{NH}_{3} \mathrm{PbI}_{3}$ perovskite film deposited on the $\mathrm{SnO}_{2}$ layer was significantly increased in the range of $450-800 \mathrm{~nm}$, which was attributed to the more complete conversion of $\mathrm{PbI}_{2}$ into $\mathrm{CH}_{3} \mathrm{NH}_{3} \mathrm{PbI}_{3}$ perovskite, as evidenced by the XRD patterns (Fig. 1). Near the $\left(\begin{array}{lll}1 & 1 & 0\end{array}\right)$ peak for the perovskite film, a diffraction peak at $12.8^{\circ}$ appeared, which was attributed to $\left(\begin{array}{lll}0 & 0 & 1\end{array}\right)$ diffraction from $\mathrm{PbI}_{2}$ crystals [34] as discussed elsewhere. Hence, a strong peak appeared in the absorption band around $440 \mathrm{~nm}$ related to the characteristic of the $\mathrm{PbI}_{2}$. On the other hand, it was generated by release of $\mathrm{CH}_{3} \mathrm{NH}_{3} \mathrm{I}$ component from the $\mathrm{CH}_{3} \mathrm{NH}_{3} \mathrm{PbI}_{3}$ perovskite. An excess amount of $\mathrm{PbI}_{2}$ in the $\mathrm{CH}_{3} \mathrm{NH}_{3} \mathrm{PbI}_{3}$ perovskite is expected to be detrimental to the device performance because of its electrical insulating properties [35]. Fig. 2b shows a companied $\mathrm{UV} /$ vis absorption spectra of the bare $\mathrm{FTO}, \mathrm{FTO} / \mathrm{SnO}_{2}$ (ethanol) and $\mathrm{FTO} / \mathrm{SnO}_{2}$ (water) films. Compared to the absorption spectrum of the bare FTO, FTO/SnO 2 (ethanol) was significantly blue shifted with high intensity and $\mathrm{FTO} / \mathrm{SnO}_{2}$ (water) was red shifted. The blue and red shifting of the absorption spectra is due size variation of the $\mathrm{SnO}_{2}$ nanoparticles [36].

The morphology of perovskite is closely related to optical and electrical properties of the device, and thus was important for enhancement of device performance. SEM images showed for bare $\mathrm{SnO}_{2}$ (Fig. 3a, b) film on the FTO using water and ethanol, respectively. Top-view $\left(\mathrm{SnO}_{2} / \mathrm{CH}_{3} \mathrm{NH}_{3} \mathrm{PbI}_{3}\right)$ and cross-sectional $\mathrm{SEM}$ images show the $\mathrm{SnO}_{2} / \mathrm{CH}_{3} \mathrm{NH}_{3} \mathrm{PbI}_{3} / \mathrm{CuSCN} / \mathrm{Au}$ 
device, with ca. $50 \mathrm{~nm}$ thick $\mathrm{SnO}_{2}$ films spin-coated using water (Fig. 4a-c) and ethanol (Fig. 5ac). Due to very small film thickness (ca. $50 \mathrm{~nm}$ ), the $\mathrm{SnO}_{2}$ surface morphology basically replicates the homogeneous morphology of the underlying FTO layer. The surface image in Fig. 3a shows that the $\mathrm{SnO}_{2}$ layer does not completely cover the FTO surface. Thus, inhomogeneous growth of $\mathrm{SnO}_{2}$ particles may occur when using water as a solvent. When $\mathrm{SnCl}_{2}$ dissolved in the water solvent, uncontrolled $\mathrm{Sn}(\mathrm{OH})_{2}$ nanoparticles may grow in solution. That $\mathrm{Sn}(\mathrm{OH})_{2}$ containing solution was deposited on FTO and then annealed in air at $200^{\circ} \mathrm{C}$ for $2 \mathrm{~h}$, resulting in formation of inhomogeneous $\mathrm{SnO}_{2}$ nanoparticles by rabid oxidation, as shown in Fig. 3a. Consequently, the perovskite film showed rough surface due to the inhomogeneous $\mathrm{SnO}_{2}$ film (Fig. 4a-b). However, when ethanol was used as the solvent for the $\mathrm{SnO}_{2}$ film, highly uniform $\mathrm{SnO}_{2}$ nanoparticles were grown directly from $\mathrm{SnCl}_{2}$ (Fig. 3b) during annealing process. Uncontrolled $\mathrm{Sn}(\mathrm{OH})_{2}$ was prevented in solution due to lack of $(\mathrm{OH})$ molecules in ethanol. Therefore the top-view of the perovskite $\left(\mathrm{SnO}_{2} / \mathrm{CH}_{3} \mathrm{NH}_{3} \mathrm{PbI}_{3}\right)$ film showed highly uniform structure with smooth surface (Fig. 5a-b).

Fig. 6 shows the performance of $\mathrm{SnO}_{2} / \mathrm{CH}_{3} \mathrm{NH}_{3} \mathrm{PbI}_{3} / \mathrm{CuSCN} / \mathrm{Au}$ device prepared by a two-step process with different solvents used for the $\mathrm{SnO}_{2}$ film. The detailed photovoltaic parameters are summarized in Table 1 . The surface of electron-selective layer is very important for obtaining high-performance devices. The inhomogeneous $\mathrm{SnO}_{2}$ layer promoted the recombination at $\mathrm{FTO} / \mathrm{CH}_{3} \mathrm{NH}_{3} \mathrm{PbI}_{3}$ interface and caused the fill factor to be reduced, as shown in Table 1 . Therefore, the photovoltaic performance only reached $6.59 \%$ when the $\mathrm{SnO}_{2}$ layer was prepared using water as solvent. However, a smooth $\mathrm{SnO}_{2}$ layer that completely covered the rough FTO surface was formed using ethanol as solvent (Figs. 4a and b) and the photovoltaic performance exhibited a distinct increase to $8.38 \%$.

Some preliminary photovoltaic experiments were conducted to evaluate the performance of devices prepared by a one-step method (Supplementary data). The contact between the $\mathrm{SnO}_{2}$ and perovskite layers was determined to play an important role in the device performance. The 
perovskite layer was in direct contact with the $\mathrm{SnO}_{2}$ layer using a one-step perovskite coating method, and as a result the photovoltaic performance was reduced (Table S1, Supplementary Information). In contrast to one-step coating method, the two-step coating procedure used in this study resulted in significant increases in the open circuit voltage (Voc), fill factor (FF), short circuit current density $\left(\mathrm{J}_{\mathrm{SC}}\right)$, and efficiency, as shown in Table 1. There may be suitable band gap alignment between the compact $\mathrm{SnO}_{2}$ and $\mathrm{PbI}_{2}$ layers. Therefore, the two-step method was adopted to coat the perovskite on the $\mathrm{SnO}_{2}$ layer for photovoltaic investigations. Figure 6 shows the J-V characteristics for a planar structure under standard AM $1.5 \mathrm{G}$ illuminations at $100 \mathrm{~mW}$ $\mathrm{cm}^{-2}$, and the photovoltaic parameters are given in Table 1 . The $\mathrm{SnO}_{2} / \mathrm{CH}_{3} \mathrm{NH}_{3} \mathrm{PbI}_{3} / \mathrm{CuSCN} / \mathrm{Au}$ device exhibited a PCE of $6.59 \%$ with a $\mathrm{J}_{\mathrm{SC}}$ of $18.19 \mathrm{~mA} \mathrm{~cm}^{-2}$, a $\mathrm{V}_{\mathrm{OC}}$ of $0.95 \mathrm{~V}$, and a FF of 0.38 when water used as solvent for $\mathrm{SnO}_{2}$ preparation. The replacement of water with ethanol as the solvent resulted in a significant increase in $\mathrm{V}_{\mathrm{OC}}, \mathrm{J}_{\mathrm{SC}}$, and $\mathrm{FF}$, achieving a PCE of $8.38 \%$ for device. The full coverage of $\mathrm{SnO}_{2}$ on the FTO layer may block direct contact between the cathode and HTM, and thus minimize current leakage. The IPCE spectrum shown in Fig. 7 indicates that photocurrent was generated up to ca. $800 \mathrm{~nm}$ for the $\mathrm{CH}_{3} \mathrm{NH}_{3} \mathrm{PbI}_{3}$ layer on the $\mathrm{SnO}_{2}$ film. From integration of the measured IPCE spectrum over the solar spectrum, a shortcircuit current density of $18.99 \mathrm{~mA} \mathrm{~cm}^{-2}$ was estimated, which is similar to the average photocurrent generated from a typical cell [37]. It should be noted that this IPCE spectrum is taken from a representative device from the batch, not the most optimal device. It was also confirmed that the perovskite solar cell could operate well, even without a mesoporous $\mathrm{TiO}_{2}$ film, where a thin, continuous $\mathrm{CH}_{3} \mathrm{NH}_{3} \mathrm{PbI}_{3}$ layer formed on the $\mathrm{SnO}_{2}$ surface exhibited good photovoltaic performance. The excellent device performance demonstrates the efficient charge collection properties of $\mathrm{SnO}_{2}$ layer in the planar device.

To investigate the internal charge carrier transport and recombination, EIS was performed from $1 \mathrm{~Hz}$ to $10 \mathrm{MHz}$ under illuminated conditions [38, 39]. Nyquist plots show various voltages from 0 to $400 \mathrm{mV}$ for water (Fig. 8a-b) and ethanol (Fig. 8c-d) used as solvents for $\mathrm{SnO}_{2}$ 
preparation. For both devices, two clear arcs in the high and lower frequency regions were observed. The high-frequency arc was assigned to the process of hole transport in solid $\mathrm{CuSCN}$, and the low-frequency arc was attributed to recombination resistance and the chemical capacitance of the perovskite film. The charge-transport resistance at the $\mathrm{CH}_{3} \mathrm{NH}_{3} \mathrm{PbI}_{3}$ $\left(\mathrm{SnO}_{2} /\right.$ ethanol)/selective contacts interface is presumably lower than that at the $\mathrm{CH}_{3} \mathrm{NH}_{3} \mathrm{PbI}_{3}$ $\left(\mathrm{SnO}_{2} /\right.$ water $) /$ selective contacts interface, leading to a lower series resistance of the device using $\mathrm{SnO}_{2} /$ ethanol. The lower charge-transport resistance (and consequently lower series resistance) of $\mathrm{SnO} 2 /$ ethanol film is caused by the high smoothness of the surface, as shown in the SEM images. (Fig. 3a). This result may be attributed to the difference between the $\mathrm{CH}_{3} \mathrm{NH}_{3} \mathrm{PbI}_{3}$ ( $\mathrm{SnO}_{2} /$ ethanol) film and the $\mathrm{CH}_{3} \mathrm{NH}_{3} \mathrm{PbI}_{3}\left(\mathrm{SnO}_{2} /\right.$ water $)$ film. As shown in Fig. 4(a-b), the $\mathrm{CH}_{3} \mathrm{NH}_{3} \mathrm{PbI}_{3}\left(\mathrm{SnO}_{2} /\right.$ water $)$ film exhibits more and larger cracks than that of $\mathrm{CH}_{3} \mathrm{NH}_{3} \mathrm{PbI}_{3}$ $\left(\mathrm{SnO}_{2} /\right.$ ethanol) film, which may reduce the carrier transport efficiency. The equivalent circuit use for fitting shown in Fig. 8e consists of one series resistance $\mathrm{R}_{\mathrm{s}}$, and two parallel resistanceconstant phase elements $(\mathrm{R} / / \mathrm{CPE}) . \mathrm{R}_{\mathrm{s}}$ is mainly the contribution from the conducting wires, contacts, and the sheet resistance of the collecting electrodes [40], and CPE is used to describe a non-ideal capacitor with a capacitive contribution and quality factor. Both devices have similar $\mathrm{R}_{\mathrm{s}}$, which is reasonable because of similar configurations of the solar cells. $\mathrm{R}_{\mathrm{a}} / / \mathrm{CPE}$ and $\mathrm{R}_{\mathrm{b}} / / \mathrm{CPE}_{\mathrm{b}}$ correspond to semicircles at high and low frequencies, respectively. $\mathrm{R}_{\mathrm{rec}}$ that is inversely related to the recombination rate and dependent on the applied bias voltage is plotted in Fig. 8f [41].

\section{Conclusions}

A high-efficiency perovskite solar cell was fabricated with new and efficient $\mathrm{SnO}_{2} \mathrm{ETM}$ layer using solid state CuSCN as HTM. The average efficiency for 3 cells using ethanol solvent with low-temperature processed $\mathrm{SnO}_{2}$ ETM was $8.29 \%$, whereas it was only $6.09 \%$ when water was used as solvent. The excellent surface smoothness of the thin film $\left(\mathrm{SnO}_{2}\right)$ using ethanol as solvent rather than water resulted in high efficiency of the device. Two-step spin-coating of $\mathrm{PbI}_{2}$ 
and $\mathrm{CH}_{3} \mathrm{NH}_{3} \mathrm{I}$ solutions led to a suitable contact between the $\mathrm{CH}_{3} \mathrm{NH}_{3} \mathrm{PbI}_{3}$ perovskite and the $\mathrm{SnO}_{2}$ film. The $\mathrm{SnO}_{2}$-based perovskite solar cell exhibited a good IPCE from 400 to $750 \mathrm{~nm}$. The robust and abundant $\mathrm{SnO}_{2}$ material promises the realization of commercial applications of $\mathrm{CH}_{3} \mathrm{NH}_{3} \mathrm{PbI}_{3}$ solar cells for low-temperature technology. The best performing planar perovskite solar cell was that with a nanocrystalline $\mathrm{SnO}_{2}$ ETM layer prepared using ethanol as a solvent, which achieved a PCE of $8.38 \%$ with a $\mathrm{J}_{\mathrm{SC}}$ of $18.99 \mathrm{~mA} \mathrm{~cm}$, a VOC of $0.96 \mathrm{~V}$, and a FF of 0.45 under forward scanning. This was much higher than that for the best cell where the $\mathrm{SnO}_{2} \mathrm{ETM}$ layer was prepared using water as solvent under the same conditions. Therefore, it was concluded that a solution method for the preparation of the $\mathrm{SnO}_{2}$ film for perovskite-based solar cells using ethanol instead of water as a solvent resulted in good photovoltaic performance. In addition, the good performance of the planar $\mathrm{SnO}_{2}$ based device showed fast saturation in charge collection, which indicates that the $\mathrm{SnO}_{2}$ nanoparticles are an effective charge collection system for $\mathrm{CH}_{3} \mathrm{NH}_{3} \mathrm{PbI}_{3}$ based perovskite solar cells. $\mathrm{SnO}_{2}$ electron conducting materials could thus provide a future contribution to the industrial fabrication of low cost planar perovskite solar cells using roll-to-roll processing on a flexible substrate at low temperature.

\section{Acknowledgement}

This work was supported by the Advanced Low Carbon Technology Research and Development Program (ALCA, JST, Japan).

\section{References:}

[1] J. Burschka, N. Pellet, S.-J. Moon, R. Humphry-Baker, P. Gao, M. K. Nazeeruddin, M. Grätzel, Nature 499 (2013) 316-319.

[2] M. Liu, M.B. Johnston, H.J. Snaith, Nature 501 (2013) 395-398.

[3] N.J. Jeon, J.H. Noh, Y.C. Kim, W.S. Yang, S. Ryu, S.I. Seok, Nature Materials 13 (2014) 897-903.

[4] H. Zhou, Q. Chen, G. Li, S. Luo, T.-B. Song, H.-S. Duan, Z. Hong, J. You, Y. Liu, Y. Yang, Science 345 (2014) 542-546. 
[5] L. Dou, Y. M. Yang, J. You, Z. Hong, W.-H. Chang, G. Li, Y. Yang, Nature Communications 5 (2014) 5404.

[6] A. Kojima, K. Teshima, Y. Shirai, T. Miyasaka, J. Am. Chem. Soc. 131 (2009) 6050-6051.

[7] J.H. Noh, S.H. Im, J.H. Heo, T.N. Mandal, S.I. Seok, Nano Lett. 13 (2013) 1764-1769.

[8] Y. Ogomi, A. Morita, S. Tsukamoto, T. Saitho, N. Fujikawa, Q. Shen, T. Toyoda, K. Yoshino, S. S. Pandey, T. Ma, S. Hayase, J. Phys. Chem. Lett. 5 (2014) 1004-1011.

[9] A. Mei, X. Li, L. Liu, Z. Ku, T. Liu, Y. Rong, M. Xu, M. Hu, J. Chen, Y. Yang, M. Grätzel, H. Han, Science 345 (2014) 295-298.

[10] G.E. Eperon, S.D. Stranks, C. Menelaou, M.B. Johnston, L.M. Herz, H.J. Snaith, Energy Environ. Sci. 7 (2014) 982-988.

[11] J. You, Z. Hong, Y. Yang, Q. Chen, M. Cai, T.-B. Song, C.-C. Chen, S. Lu, Y. Liu, H. Zhou, Y. Yang, ACS Nano 8 (2014) 1674-1680.

[12] Q. Zhang, C. Dandeneau, X. Zhou, G. Cao, Adv. Mater. 21 (2009) 4087-4108.

[13] Y. Shi, K. Wang, Y. Du, H. Zhang, J. Gu, C. Zhu, L. Wang, W. Guo, A. Hagfeldt, N. Wang, T. Ma, Adv. Mater. 25 (2013) 4413-4419.

[14] D. Liu, T. Kelly, Nature Photonics 8 (2014) 133-138.

[15] P. Tiwana, P. Docampo, M. B. Johnston, H. J. Snaith, L. M. Herz, ACS Nano. 5 (2011) $5158-5166$

[16] P. Qin, S. Tanaka, S. Ito, N. Tetreault, K. Manabe, H. Nishino, M.K. Nazeeruddin, M. Grätzel, Nature Communications 5 (2014) 3834.

[17] C. Chappaz-Gillot, S. Berson, R. Salazar, B. Lechene, D. Aldakov, V. Delaye, S. Guillerez, V. Ivanova, Sol. Energy Mater. Sol. Cells 120 (2014) 163-167.

[18] B. Li, L.D. Wang, B.N. Kang, P. Wang, Y. Qiu, Sol. Energy Mater. Sol. Cells 90 (2006) $549-573$.

[19] P. Pattanasattayavong, G.O.N. Ndjawa, K. Zhao, K.W. Chou, N. Yaacobi-Gross, B.C. O’Regan, A. Amassian, T.D Anthopoulos, Chem. Commun. 49 (2013) 4154-4156. 
[20] P. Pattanasattayavong, N. Yaacobi-Gross, K. Zhao, G.O.N. Ndjawa, J.H. Li, F. Yan, B.C. O’Regan, A. Amassian, T.D. Anthopoulos, Adv. Mater. 25 (2013) 1504-1509.

[21] B. Bob, T.-B. Song, Chen, C.-C.; Xu, Z.; Yang, Y. Chem. Mater. 25 (2013) 4725-4730.

[21] H.J. Snaith, C. Ducati, Nano Lett. 10 (2010) 1259-1265.

[23] Q. Dong, Y. Shi, K. Wang, Y. Li, S. Wang, H. Zhang, Y. Xing, Y. Du, X. Bai, T. Ma, J. Phys. Chem. C 119 (2015) 10212-10217.

[24] Y. Li, J. Zhu, Y. Huang, F. Liu, M. Lv, S. Chen, L. Hu, J. Tang, J. Yaod, S. Dai, RSC Adv. 5 (2015) 28424-28429.

[25] J. Song, E. Zheng, J. Bian, X.F. Wang, W. Tian, Y. Sanehira, T. Miyasaka, J. Mater. Chem. A 3 (2015) 10837-10844.

[26] Z. Zhu, X. Zheng, Y. Bai, T. Zhang, Z. Wang, S. Xiao, S. Yang, Phys. Chem. Chem. Phys. 17 (2015) 18265-18268.

[27] G.E. Eperon, V.M. Burlakov, P. Docampo, A. Goriely, H.J. Snaith, Adv. Funct. Mater. 24 (2014) 151-157.

[28] J.J. Choi, X. Yang, Z.M. Norman, S.J.L. Billinge, J.S. Owen, Nano Lett. 14 (2014) 127133.

[29] N. Li, H. Dong, H. Dong, J. Li, W. Li, G. Niu, X. Guo, Z. Wu, L. Wang, J. Mater. Chem. A 2 (2014) 14973-14978.

[30] Q. Wang, Y. Shao, Q. Dong, Z. Xiao, Y. Yuan, J. Huang, Energy Environ. Sci. 7 (2014) $2359-2365$.

[31] M. Grätzel, Nat. Mater. 13 (2014) 838-842.

[32] P.A. Beckmann, Cryst. Res. Technol. 45 (2010) 455-460.

[33] T. Baikie, Y. Fang, J.M. Kadro, M. Schreyer, F. Wei, S.G. Mhaisalkar, M. Grätzel, T.J. White, J. Mater. Chem. A 1 (2013) 5628-5641.

[34] Y. Wu, A. Islam, X. Yang, C. Qin, J. Liu, K. Zhang, W. Peng, L. Han, Energy Environ. Sci. 7 (2014) 2934-2938. 
[35] T. Supasai, N. Rujisamphan, K. Ullrich, A. Chemseddine, T. Dittrich, Appl. Phys. Lett. 103 (2013) 183906.

[36] G. Murugadoss, B. Rajamannan, V. Ramasamy, J. Lumin. 130 (2010) 2032-2039.

[37] G. Murugadoss, G. Mizuta, S. Tanaka, H. Nishino, T. Umeyama, H. Imahori, S. Ito, APL Materials 2 (2014) 081511-081516.

[38] Q. Wang, J.-E. Moser, M.J. Grätzel, Phys. Chem. B 109 (2005) 14945-14953.

[39] A. Dualeh, T. Moehl, N. Tétreault, J. Teuscher, P. Gao, M.K. Nazeeruddin, M. Grätzel, ACS Nano 8 (2013) 362-373.

[40] R. Trevisan, M. Döbbelin, P.P. Boix, E.M. Barea, R. Tena-Zaera, I. Mora-Seró, Adv. Energy Mater. 1 (2011) 781-784.

[41] J.A. Christians, R.C.M. Fung, P.V. Kamat, J. Am. Chem. Soc. 136 (2013) 758-764. 
Table 1. Average photovoltaic performance of perovskite solar cells using 3 cells. The perovskite film prepared on $\mathrm{SnO}_{2}$ by two step method. The values in the brackets show the results for the cells with the best efficiencies.

\begin{tabular}{|c|c|c|c|c|}
\hline Sample details & $\begin{array}{c}\text { Current density } \\
\left(\mathbf{m A ~ c m}^{-2}\right)\end{array}$ & $\begin{array}{c}\text { Voltage / } \\
(\mathbf{V})\end{array}$ & Fill Factor & $\begin{array}{c}\text { Efficiency } \\
(\mathbf{\%})\end{array}$ \\
\hline $\mathrm{SnO}_{2} /$ Ethanol & $18.98(18.99)$ & $0.96(0.96)$ & $45(45)$ & $8.29(8.38)$ \\
\hline $\mathrm{SnO}_{2} /$ Water & $17.54(18.19)$ & $0.90(0.95)$ & $0.38(0.38)$ & $6.09(6.59)$ \\
\hline
\end{tabular}




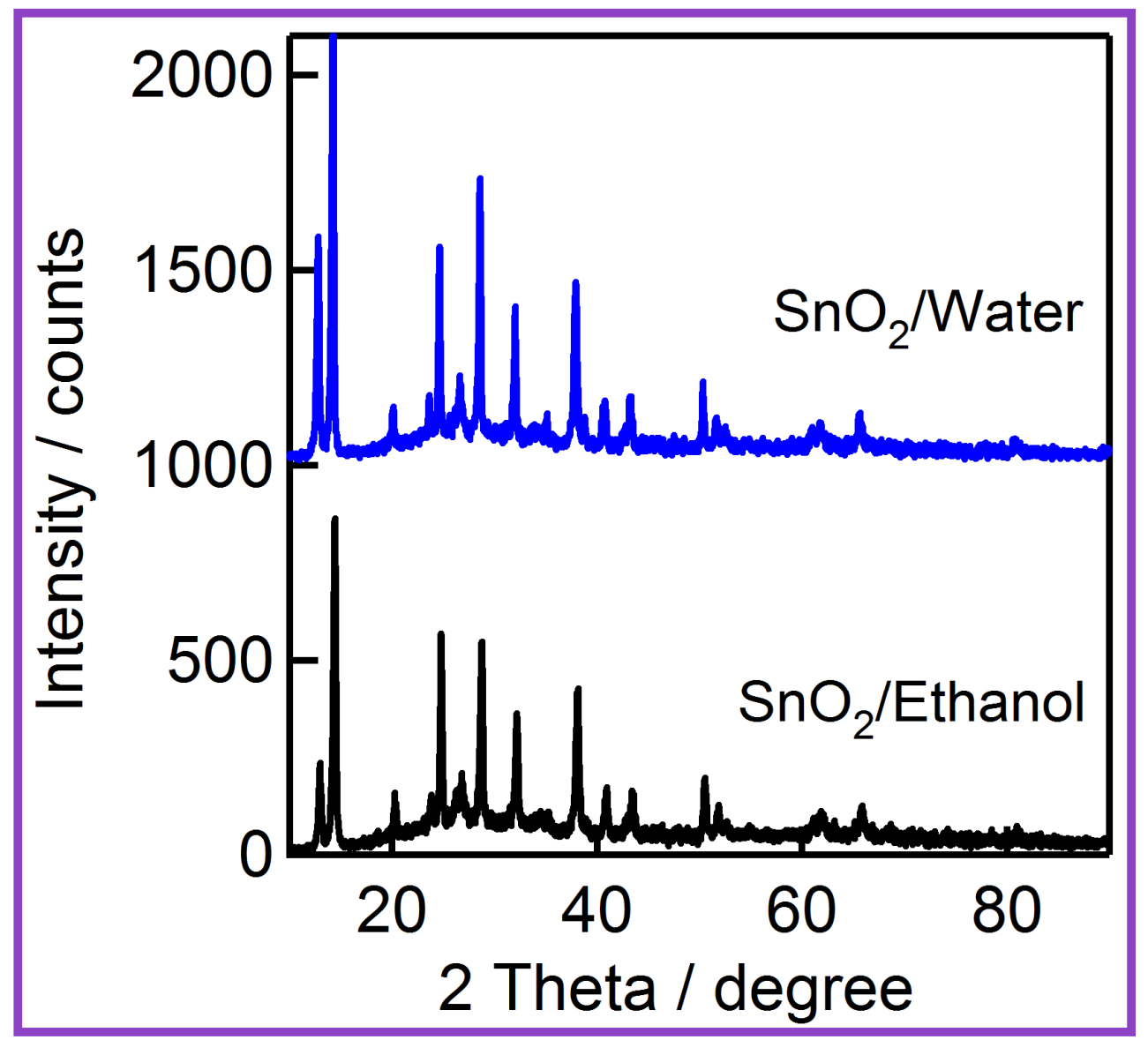

Fig. 1 


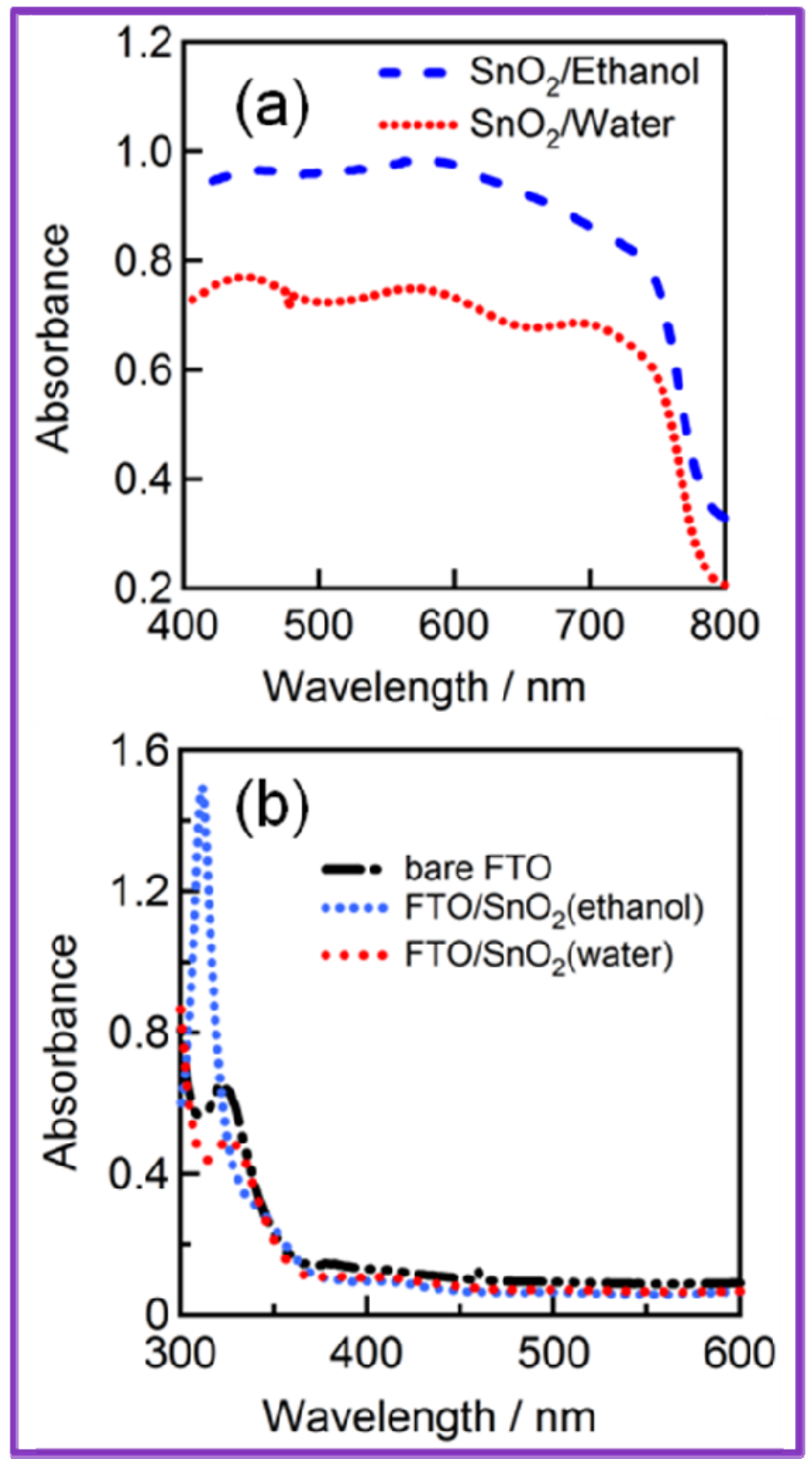

Fig. 2 (a, b) 


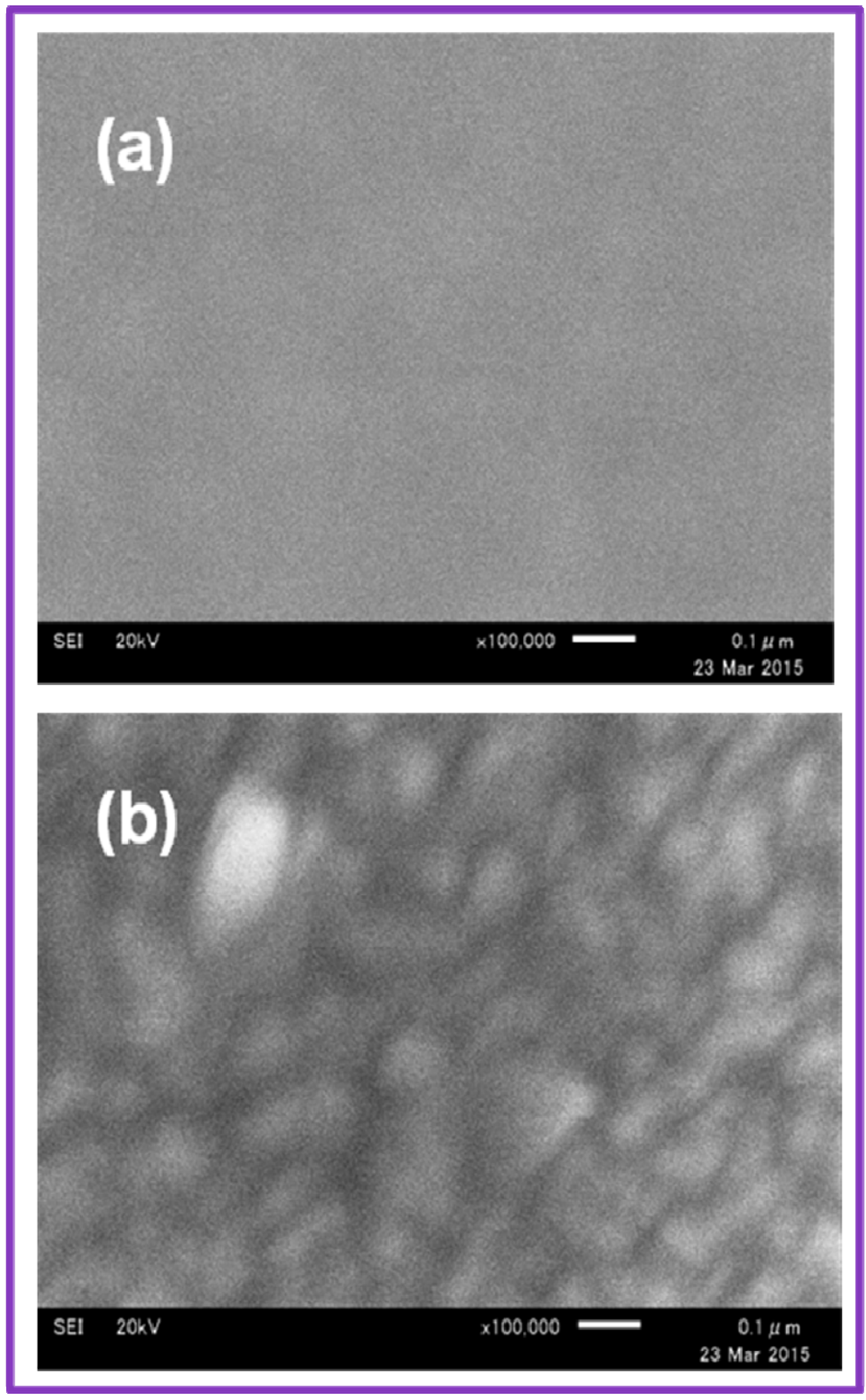

Fig. 3(a, b) 

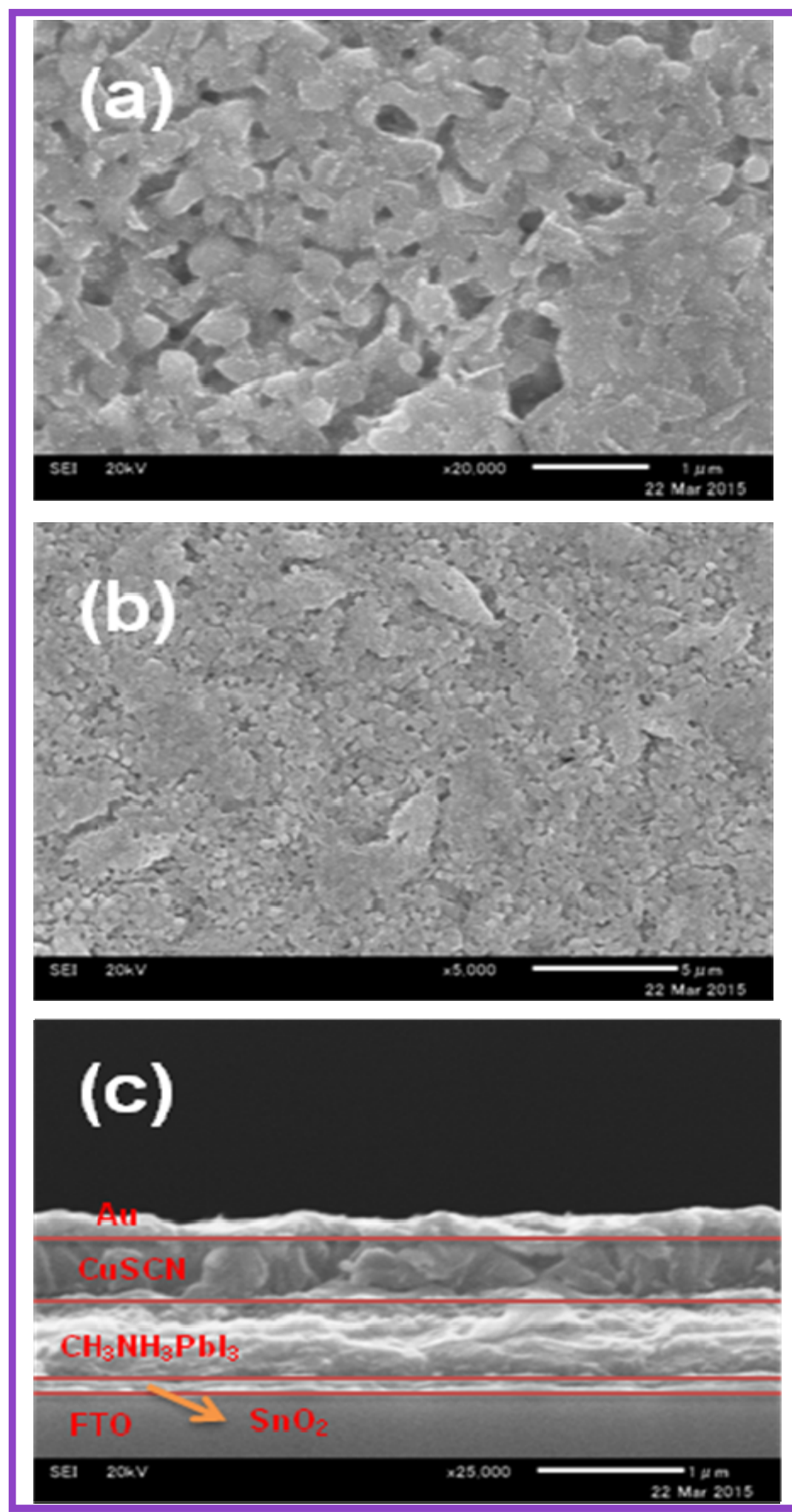

Fig. 4(a-c) 


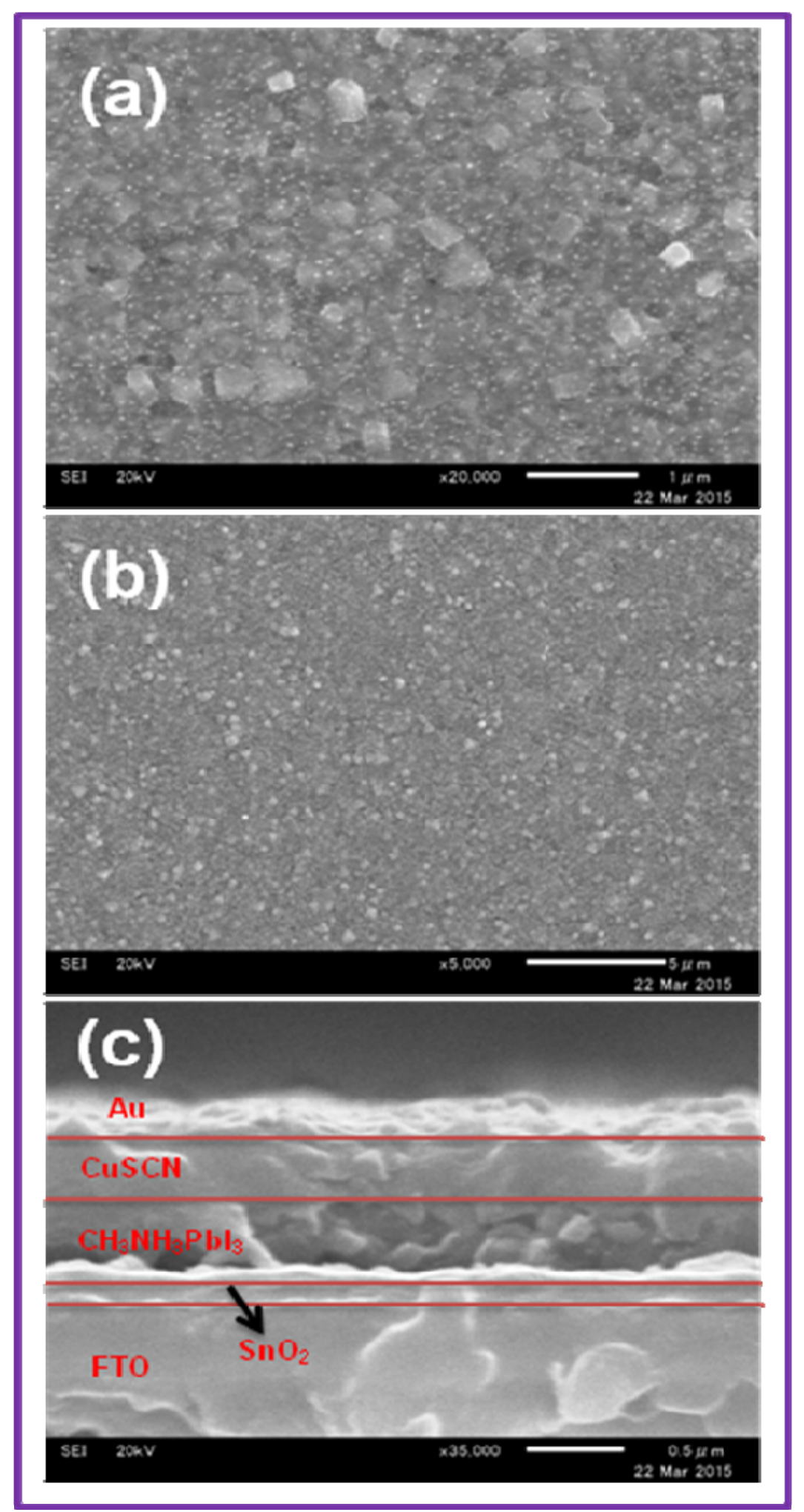

Fig. 5(a-c) 


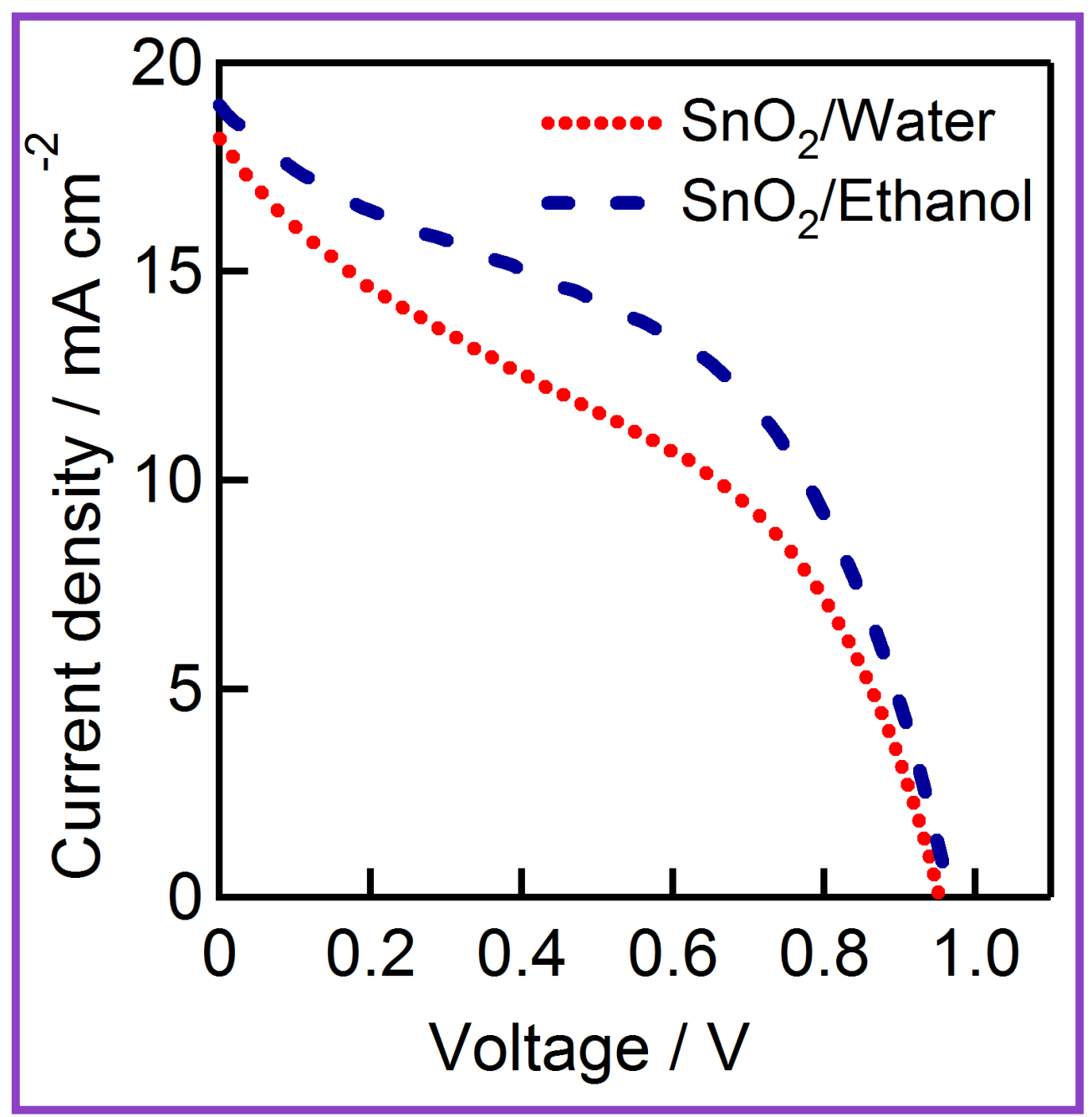

Fig. 6 


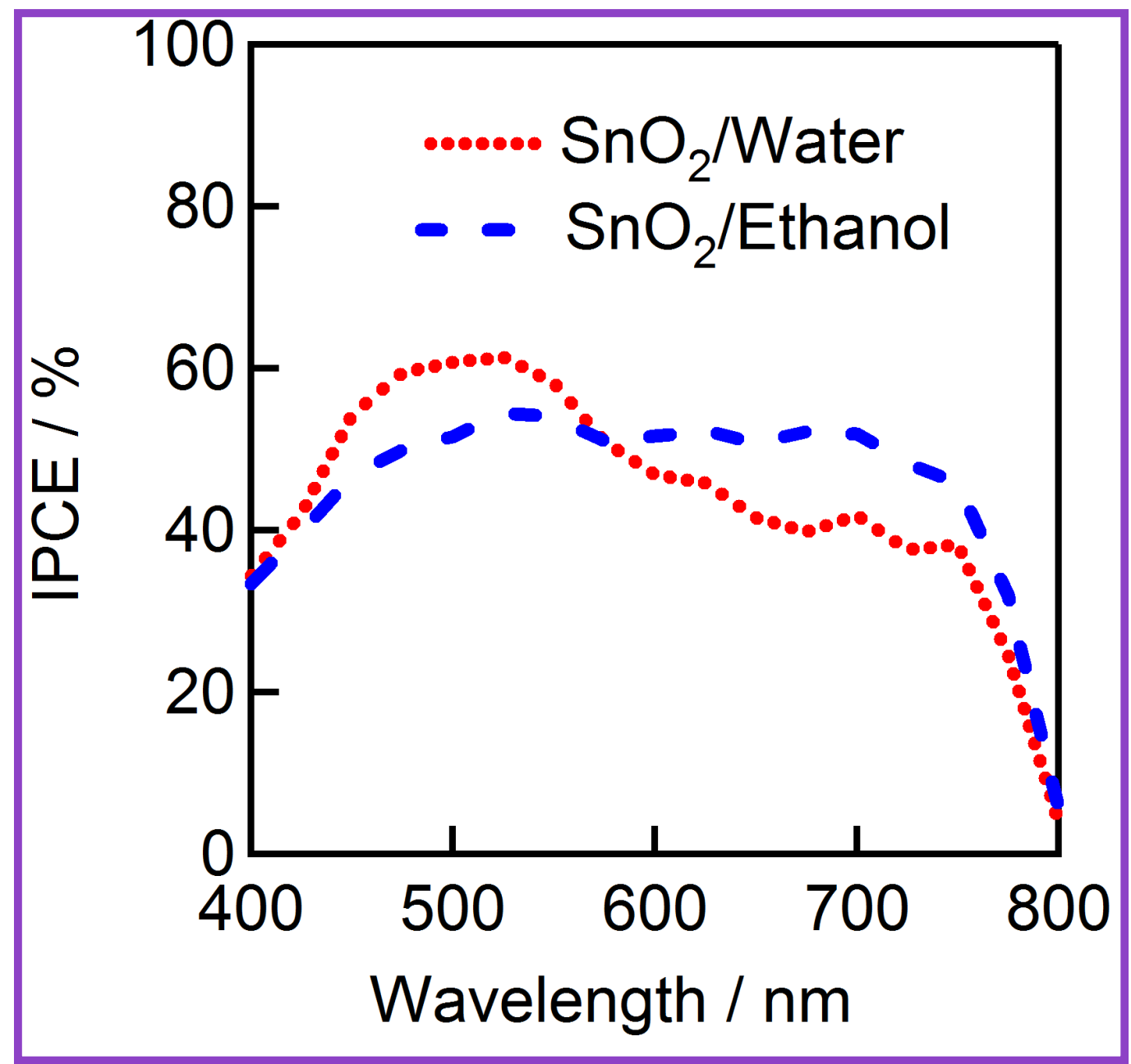

Fig. 7 

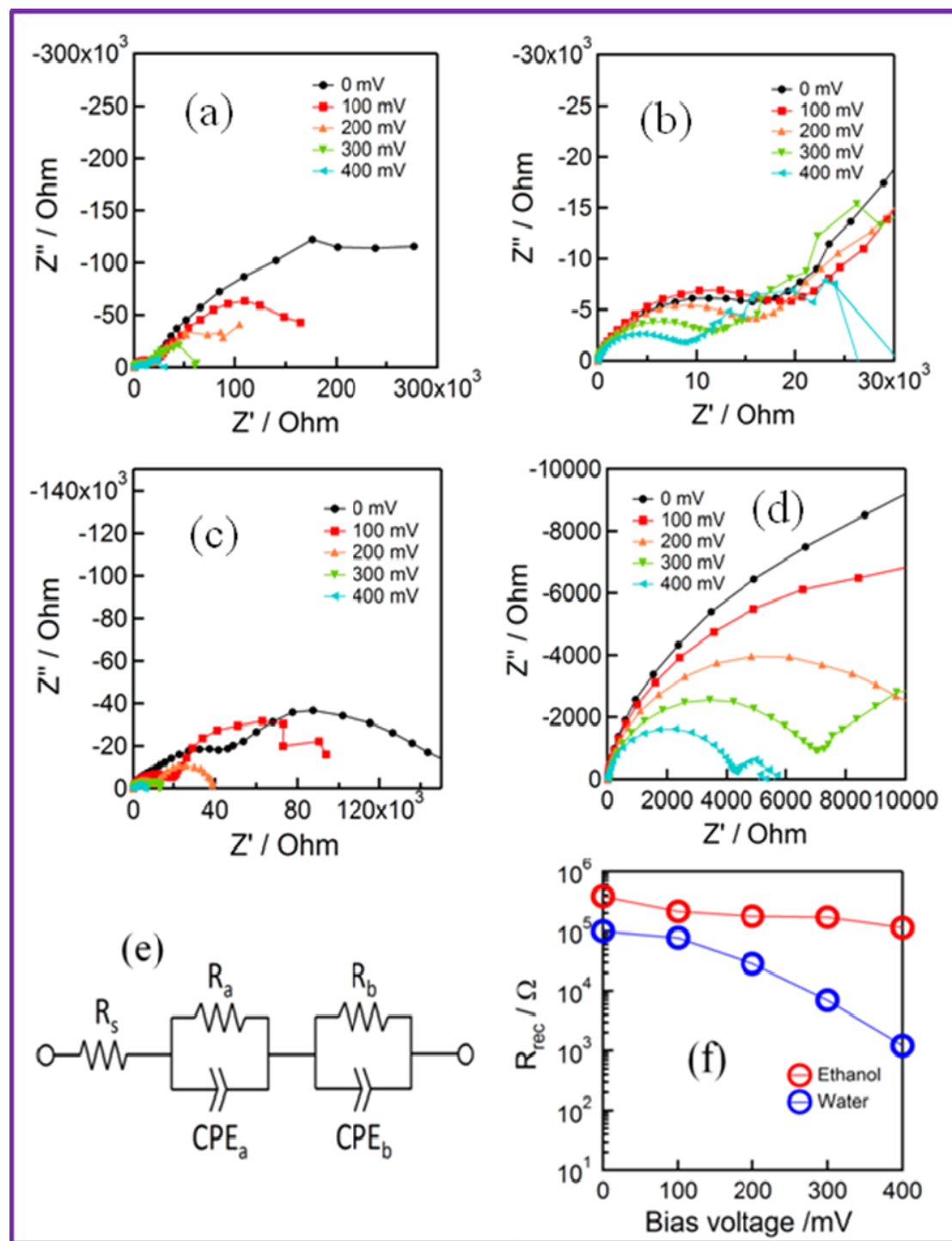

Fig. 8(a-f) 